\title{
Antiproliferative and Apoptotic Effects of the Medicinal Plants on Breast Cancer Cell Lines ${ }^{\dagger}$
}

\author{
Pınar Kılıçaslan Sönmez 1,* , Gülşah Albayrak 1, Mahmud Özkut 1, Büşra Şen 1, Pelin Toros 1, \\ Şamil Öztürk ${ }^{2}$, Fatih Çöllü̈ ${ }^{3}$, Sevinç İnan ${ }^{4}$ and Mehmet İbrahim Tuğlu ${ }^{1}$ \\ 1 Department of Histology and Embryology, Faculty of Medicine, Celal Bayar University, Manisa 45000, \\ Turkey; klcsln.pnr@gmail.com (G.A.); gulsahalbayrak@outlook.com (M.O.); \\ mahmudozkut@yahoo.com (B.S.); torospelin@gmail.com (P.T.); mituglu@yahoo.com (M.İ.T.) \\ 2 Medical Services and Techniques, Çanakkale Vocational School of Health Services, \\ Çanakkale Onsekiz Mart University, Çanakkale 17100, Turkey; samilozturk16@hotmail.com \\ 3 Department of Biology, Faculty of Science, Celal Bayar University, Manisa 45000, Turkey; \\ fatih.collu@gmail.com \\ 4 Department of Histology and Embryology, Faculty of Medicine, İzmir University of Economics, \\ İzmir 35330, Turkey; sevincinan@yahoo.com \\ * Correspondence: klcsln.pnr@gmail.com; Tel.: +90-553-421-0753 \\ + Presented at the 2nd International Conference on Natural Products for Cancer Prevention and Therapy, \\ Kayseri, Turkey, 8-11 November 2017.
}

Published: 10 November 2017

\begin{abstract}
Inula viscosa, Rubus caesius and Viscum album known as medicinal plants which have therapeutic properties in treatment of various diseases and particularly cancer. In this study, we aimed to show their anti-proliferative and apoptotic effects on MCF-7, MDA-MB-231, 67NR and 4T1 breast cancer cell lines. The cell lines were cultured to determine the cell growth using the MTT assay. Cells were cultured to evaluate for eNOS, VEGF and apoptosis by immunocytochemical staining and TUNEL assay. Statistical analysis was performed with the H-score. Inula viscosa, Rubus caesius and Viscum album extracts were found to significantly inhibit the growth of breast cancer cell lines in dose and time-dependent manner. eNOS staining was significantly increased and VEGF was decreased after extract application at IC50 dose. Similarly, results indicated that the treated breast cancer cell lines exhibited a marked increase in apoptosis. We showed that the toxic effect of Inula viscosa, Rubus caesius and Viscum album extracts created by oxidative stress and apoptotic mechanisms. Our findings suggested that due to their anticancer potential, these plants may be used as an alternative treatment for the management of cancer. Therefore future studies will focus on the identification of the molecules responsible for the anticancer activity.
\end{abstract}

Keywords: Antiproliferative; oxidative stress; apoptosis

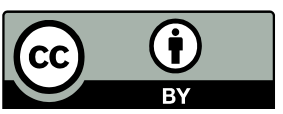

(C) 2017 by the authors. Licensee MDPI, Basel, Switzerland. This article is an open access article distributed under the terms and conditions of the Creative Commons Attribution (CC BY) license (http://creativecommons.org/licenses/by/4.0/). 